\title{
Formaldehyde and urea removal in a denitrifying granular sludge blanket reactor
}

\author{
M. Eiroa, C. Kennes, M.C. Veiga \\ Water Research, Volume 38, Issue 16, September 2004, Pages 3495-3502 \\ DOI: $10.1016 /$ j.watres.2004.04.055
}

\begin{abstract}
Simultaneous formaldehyde biodegradation, urea hydrolysis and denitrification in anoxic batch assays and in a continuous laboratory anoxic reactor were investigated. In batch assays, the initial formaldehyde biodegradation rate was around $0.7 \mathrm{~g} \mathrm{CH}_{2} \mathrm{O}$ g $\mathrm{VSS}^{-1} \mathrm{~d}^{-1}$ and independent of the urea concentration (90- $370 \mathrm{mg} \mathrm{N}-\mathrm{NH}_{2} \mathrm{CONH}_{2} \mathrm{l}^{-1}$ ). Urea was completely hydrolyzed to ammonium in the presence of $430 \mathrm{mg} \mathrm{l}^{-1}$ formaldehyde and complete denitrification took place in all cases (125 $\mathrm{mg} \mathrm{N}-\mathrm{NO}_{3}^{-} \mathrm{l}^{-1}$ ). Formaldehyde removal efficiencies above $99.5 \%$ were obtained in a lab-scale denitrifying upflow sludge blanket reactor at organic loading rates between 0.37 and $2.96 \mathrm{~kg} \mathrm{COD} \mathrm{m}^{-3} \mathrm{~d}^{-1}\left(625-5000 \mathrm{mg} \mathrm{CH}_{2} \mathrm{O} \mathrm{l}^{-1}\right)$. The urea loading rate was increased from 0.06 to $0.44 \mathrm{~kg} \mathrm{~N} \mathrm{~m}^{-3} \mathrm{~d}^{-1}\left(100-800 \mathrm{mg} \mathrm{N}-\mathrm{NH}_{2} \mathrm{CONH}_{2} \mathrm{l}^{-1}\right)$ and hydrolysis to ammonium was around $77.5 \%$ at all loading rates. The denitrification process was

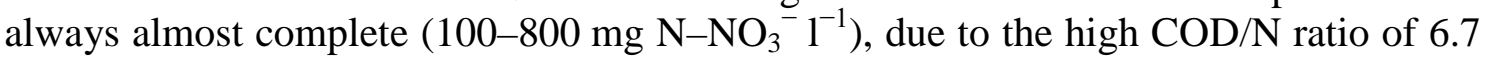
in the influent. A minimum value of 3.5 was found to be required for full denitrification. The composition of the biogas indicated that denitrification and methanogenesis occurred simultaneously in the same unit. A good granulation of the sludge was observed.
\end{abstract}

\section{Keywords}

Formaldehyde; Urea; Biodegradation; Hydrolysis; Denitrification; Granulation

\section{Introduction}

Aminoplastic resin producing industries generate wastewater with high concentrations of nitrogen compounds ( $\mathrm{TKN}=56-1462 \mathrm{mg} \mathrm{l}^{-1}$ ) and organic matter (COD=117$6851 \mathrm{mg} \mathrm{l}^{-1}$ ). Therefore, the treatment of this wastewater requires the simultaneous removal of nitrogen compounds and organic matter, which can be undertaken by biological processes. The nitrogen compounds are present mainly in the form of urea and the organic matter mainly as formaldehyde. The biological treatment can be carried out in a pre-denitrification system. Formaldehyde biodegradation, hydrolysis of urea and denitrification of nitrate recirculated from the aerobic unit would take place in the anoxic reactor. Nitrification of the ammonium provided by the anoxic unit and biodegradation of the formaldehyde that would not have been removed in the anoxic reactor would take place in the aerobic reactor. In order to optimize the operation of an industrial-scale wastewater treatment plant treating effluents which contain these compounds, the simultaneous formaldehyde biodegradation and nitrification process 
were previously studied in aerobic batch assays (Eiroa et al., 2004) and in an activated sludge reactor (Eiroa et al., in prep.), while the simultaneous formaldehyde biodegradation, urea hydrolysis and denitrification were studied in this research.

Formaldehyde is a common compound used in a wide variety of processes and frequently found in wastewaters and waste gases (Prado et al., 2003). Because of its toxicity, its presence is expected to partly inhibit the biological processes in wastewater treatment plants. Nevertheless, formaldehyde is known to be biodegradable in both aerobic (Azachi et al., 1995; Yamazaki et al., 2001; Hidalgo et al., 2002) and anaerobic systems (Qu and Bhattacharya, 1997; Lu and Hegemann, 1998; Omil et al., 1999).

Urea is hydrolyzed by microorganisms to ammonium and carbon dioxide. Latkar and Chakrabarti (1994) studied the biological hydrolysis of urea in an anaerobic system, using methanol as carbon source. They achieved urea hydrolysis with an efficiency of $100 \%$ at urea loading rates up to $1.5 \mathrm{~kg} \mathrm{~N} \mathrm{~m}^{-3} \mathrm{~d}^{-1}$. Garrido et al. (2001) worked with a multifed upflow filter under anoxic conditions using formaldehyde as carbon source. They obtained hydrolysis percentages between $65 \%$ and $85 \%$ at an urea loading rate of $0.46 \mathrm{~kg} \mathrm{~N}-\mathrm{NH}_{2} \mathrm{CONH}_{2} \mathrm{~m}^{-3} \mathrm{~d}^{-1}$.

During the denitrification process, nitrate is reduced to molecular nitrogen using a source of organic carbon, which is the electron donor to be oxidized. The optimum $\mathrm{COD} / \mathrm{N}$ ratio for denitrification depends on the nature of the carbon source. Using formaldehyde as the electron donor, the stoichiometric equation is as follow:

$5 \mathrm{CH}_{2} \mathrm{O}+4 \mathrm{NO}_{3}^{-} \rightarrow 2 \mathrm{~N}_{2}+5 \mathrm{CO}_{2}+3 \mathrm{H}_{2} \mathrm{O}+4 \mathrm{OH}^{-}$

The theoretical formaldehyde requirement for denitrifying nitrate, if biomass production is not considered, corresponds to a COD/N ratio of 2.89. In practice this ratio is higher because of the assimilation of formaldehyde for biomass synthesis. Chen and Lin (1993) showed that if anaerobic bacteria are maintained in a denitrifying reactor, the methanogenic activity starts only after the denitrification step. Thus, the excess organic carbon remaining after denitrification can be converted to methane and carbon dioxide (Her and Huang, 1995).

The purpose of the present research was to study the simultaneous formaldehyde biodegradation, urea hydrolysis and denitrification in anoxic batch assays and in a continuous lab-scale anoxic reactor. The biodegradability of formaldehyde and its effects on urea hydrolysis and denitrification were investigated.

\section{Materials and methods}

\subsection{Analytical methods}

Formaldehyde was analyzed spectrophotometrically according to the Hantzch reaction (Nash, 1953). Methanol and formic acid were measured by gas and liquid chromatography, respectively; and nitrite and nitrate were determined by capillary electrophoresis as described elsewhere (Eiroa et al., 2004).

Ammonium was measured with a selective Ingold electrode (APHA, 1998). pH, COD and VSS were evaluated according to Standard Methods ( APHA, 1998). Biogas composition $\left(\mathrm{N}_{2}, \mathrm{CH}_{4}, \mathrm{CO}_{2}\right.$ and $\left.\mathrm{N}_{2} \mathrm{O}\right)$ was analyzed on a Hewlett Packard 5890-II gas 
chromatograph equipped with a Porapack Q W80/100 column ( $2 \mathrm{~m} \times \frac{1}{8}$ in ID) and a thermal conductivity detector. Helium $\left(15 \mathrm{ml} \mathrm{min}^{-1}\right)$ was utilized as carrier gas. Injector, oven and detector temperatures were $90^{\circ} \mathrm{C}, 25^{\circ} \mathrm{C}$ and $100^{\circ} \mathrm{C}$, respectively.

The samples of sludge for scanning electron microscopy were fixed using 3\% glutaraldehyde and $1 \%$ osmium tetroxide in $0.025 \mathrm{~mol} \mathrm{l}^{-1}$ phosphate buffer at $\mathrm{pH} 7$. The samples were then dehydrated using different aqueous ethanol solutions (30\%, $50 \%$, $70 \%, 90 \%$ and $100 \%)$. The dehydrated samples were critical point dried using liquid carbon dioxide and mounted on metal stubs. These were then sputter-coated with gold and examined using a Jeol Scanning Microscope JSM-6400.

\subsection{Batch assays}

After some preliminary experiments that allowed defining the most appropriate operating conditions, denitrifying batch assays were undertaken in $300 \mathrm{ml}$ vials filled with $250 \mathrm{ml}$ medium. Each flask was inoculated with $2 \mathrm{~g} \mathrm{VSS} \mathrm{l}^{-1}$, using sludge obtained from the anoxic chamber of the full-scale wastewater treatment plant of a synthetic resin producing factory (Cantó et al., 1998). The initial $\mathrm{pH}$ was adjusted to 7.5; $\mathrm{NaHCO}_{3}$ was used as $\mathrm{pH}$ buffer. The medium was supplemented with $2.5 \mathrm{ml}$ nutrient solution composed of $\left(\mathrm{g} \mathrm{l}^{-1}\right): \mathrm{CaCl}_{2} \cdot 2 \mathrm{H}_{2} \mathrm{O} \quad 1.00, \quad \mathrm{FeSO}_{4} \cdot 7 \mathrm{H}_{2} \mathrm{O} \quad 0.50, \mathrm{MnCl}_{2} \cdot 4 \mathrm{H}_{2} \mathrm{O} \quad 0.25$, $\left(\mathrm{NH}_{4}\right)_{6} \mathrm{Mo}_{7} \mathrm{O}_{24} \cdot 4 \mathrm{H}_{2} \mathrm{O} \quad 0.05, \mathrm{CuSO}_{4} \cdot 5 \mathrm{H}_{2} \mathrm{O} \quad 0.05, \mathrm{MgSO}_{4} \cdot 7 \mathrm{H}_{2} \mathrm{O} 2.40$ and $\mathrm{CoCl}_{2} \cdot 6 \mathrm{H}_{2} \mathrm{O}$ 0.001 . The COD/N/P ratio was adjusted to $200 / 5 / 1$ by adding $\mathrm{NH}_{4} \mathrm{Cl}$ and $\mathrm{KH}_{2} \mathrm{PO}_{4}$. Then, $125 \mathrm{mg} \mathrm{N}-\mathrm{NO}_{3}^{-} \mathrm{l}^{-1}$, $430 \mathrm{mg} \mathrm{CH}_{2} \mathrm{Ol}^{-1}$ (COD/N: 3.7) and urea concentrations ranging from 90 to $370 \mathrm{mg} \mathrm{N}-\mathrm{NH}_{2} \mathrm{CONH}_{2} \mathrm{l}^{-1}$ were added. Finally, the flasks were sealed and nitrogen gas was passed through the head space for $5 \mathrm{~min}$ in order to remove oxygen. Assays were performed in a thermostatic chamber at $20^{\circ} \mathrm{C}$ with a constant shaking at $200 \mathrm{rpm}$.

\subsection{Continuous reactor}

A lab-scale anoxic upflow sludge blanket reactor, made of glass with a length of $45 \mathrm{~cm}$, an inner diameter of $5.5 \mathrm{~cm}$ and an effective volume of $0.92 \mathrm{l}$, was used for continuous assays. The system was provided with a liquid displacement biogas measurement device (Veiga et al., 1990). The reactor was inoculated with $8 \mathrm{~g} \mathrm{VSS}^{-1}$ of anoxic sludge from the full-scale wastewater treatment plant of a synthetic resin producing factory (Cantó et al., 1998). The influent was supplied to the reactor with a peristaltic pump at $0.51 \mathrm{ld}^{-1}$ and a recirculation rate of $7.7 \mathrm{l} \mathrm{d}^{-1}$ was used, being the upflow velocity $0.14 \mathrm{~m} \mathrm{~h}^{-1}$. The hydraulic retention time was $1.8 \mathrm{~d}$. The temperature was around $20^{\circ} \mathrm{C}$ and the $\mathrm{pH}$ was between 7.6 and 8.7 (mean value 8.2).

The influent consisted of a synthetic solution containing $\mathrm{CH}_{2} \mathrm{O}, \mathrm{NH}_{2} \mathrm{CONH}_{2}, \mathrm{KNO}_{3}$, $\mathrm{KH}_{2} \mathrm{PO}_{4}, \mathrm{~K}_{2} \mathrm{HPO}_{4}$ and $10 \mathrm{ml} \mathrm{l}^{-1}$ of the nutrient solution mentioned before. Formaldehyde, urea and nitrate concentrations in the influent were increased stepwise from 625 to $5000 \mathrm{mg} \mathrm{CH}_{2} \mathrm{Ol}^{-1}, 100$ to $800 \mathrm{mg} \mathrm{N}-\mathrm{NH}_{2} \mathrm{CONH}_{2} \mathrm{l}^{-1}$ and 100 to $800 \mathrm{mg}$ $\mathrm{N}-\mathrm{NO}_{3}{ }^{-} \mathrm{l}^{-1}$; maintaining the $\mathrm{COD} / \mathrm{N}$ ratio at 6.7 . Afterwards, the urea and nitrate concentrations were maintained at $800 \mathrm{mg} \mathrm{N}-\mathrm{NH}_{2} \mathrm{CONH}_{2} \mathrm{l}^{-1}$ and $800 \mathrm{mg} \mathrm{N}-\mathrm{NO}_{3}^{-} \mathrm{l}^{-1}$, and the formaldehyde concentration was changed stepwise to obtain different COD/N ratios between 6.7 and 3.2 (Table 1). 
Table 1.

Formaldehyde, urea and nitrate concentration and COD/N ratio in the influent

\begin{tabular}{|c|c|c|c|c|}
\hline Time (d) & $\mathrm{CH}_{2} \mathrm{O}\left(\mathrm{mg} \mathrm{l}^{-1}\right)$ & $\mathrm{N}-\mathrm{NH}_{2} \mathrm{CONH}_{2}\left(\mathrm{mg} \mathrm{l}^{-1}\right)$ & $\mathrm{N}-\mathrm{NO}_{3}{ }^{-}\left(\mathrm{mg} \mathrm{l}^{-1}\right)$ & COD/N \\
\hline $0-11$ & 625 & 0 & 100 & 6.7 \\
\hline $12-26$ & 625 & 100 & 100 & 6.7 \\
\hline $27-45$ & 1250 & 200 & 200 & 6.7 \\
\hline $46-71$ & 1875 & 300 & 300 & 6.7 \\
\hline $72-85$ & 2500 & 400 & 400 & 6.7 \\
\hline $86-106$ & 3125 & 500 & 500 & 6.7 \\
\hline $107-120$ & 3750 & 600 & 600 & 6.7 \\
\hline 121-134 & 4375 & 700 & 700 & 6.7 \\
\hline 135-148 & 5000 & 800 & 800 & 6.7 \\
\hline 149-164 & 3600 & 800 & 800 & 4.8 \\
\hline 165-183 & 2800 & 800 & 800 & 3.7 \\
\hline 184-199 & 2400 & 800 & 800 & 3.2 \\
\hline $200-220$ & 2600 & 800 & 800 & 3.5 \\
\hline $221-228$ & 2400 & 800 & 800 & 3.2 \\
\hline
\end{tabular}

\section{Results and discussion}

\subsection{Batch assays}

\subsubsection{Formaldehyde biodegradation}

In batch assays, biodegradation of $430 \mathrm{mg} \mathrm{l}^{-1}$ formaldehyde was studied both without urea and at urea concentrations ranging from 90 to $370 \mathrm{mg} \mathrm{N}-\mathrm{NH}_{2} \mathrm{CONH}_{2} \mathrm{l}^{-1}$. Complete formaldehyde biodegradation took place in less than $30 \mathrm{~h}$ (data not shown). Very similar initial biodegradation rates, around $0.7 \mathrm{~g} \mathrm{CH}_{2} \mathrm{O} \mathrm{g} \mathrm{VSS}{ }^{-1} \mathrm{~d}^{-1}$, were obtained in all assays, indicating the relatively fast removal of formaldehyde. Its removal was not affected by the initial urea concentration.

In similar assays performed in our laboratory in a nitrifying medium, formaldehyde was also completely biodegraded (Eiroa et al., 2004). Higher initial formaldehyde biodegradation rates were obtained in nitrifying assays reaching a value of $1.2 \mathrm{~g}$ $\mathrm{CH}_{2} \mathrm{O}$ g VSS ${ }^{-1} \mathrm{~d}^{-1}$ for $430 \mathrm{mg} \mathrm{l}^{-1}$ formaldehyde.

\subsubsection{Urea hydrolysis}

The urea concentrations tested ranged from 90 to $370 \mathrm{mg} \mathrm{N}-\mathrm{NH}_{2} \mathrm{CONH}_{2} \mathrm{l}^{-1}$. Ammonium concentrations produced from urea hydrolysis are shown in Fig. 1. It can be concluded that urea was completely hydrolyzed to ammonium in the presence of $430 \mathrm{mg} \mathrm{l}^{-1}$ formaldehyde, as indicated by the ammonium concentrations reached at the end of the assays. The ammonium concentrations at the end of the experiment were in 
all cases about $80 \mathrm{mg} \mathrm{N}^{-1}$ higher than the theoretical value irrespective of the initial urea concentration, as a result of the presence of some compounds in the sludge hydrolyzed to ammonium. Such conclusion was confirmed in assays without urea in which the same ammonium concentration was detected. The data show that complete hydrolysis was achieved in about 2 days at the lowest concentration while about one week was necessary at the highest concentration, because very similar initial urea hydrolysis rates were obtained in all assays. Afterwards, the ammonium concentration remained almost constant.

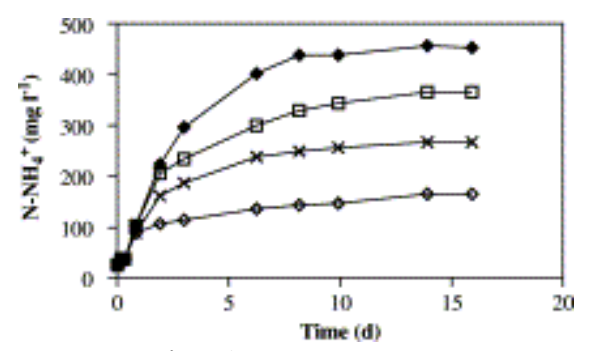

Fig. 1.

Evolution of ammonium concentrations in assays with $(\diamond) 90,(\times) 180,(\square) 280$ and ( $) 370 \mathrm{mg} \mathrm{N}-\mathrm{NH}_{2} \mathrm{CONH}_{2} \mathrm{l}^{-1}$.

\subsubsection{Denitrification process in the presence of formaldehyde and urea}

Biological denitrification in the presence of formaldehyde and urea was investigated in batch assays. The nitrite and nitrate concentrations are presented in Fig. 2. A COD/N ratio of 3.7 was used by introducing $430 \mathrm{mg} \mathrm{CH}_{2} \mathrm{O} \mathrm{l}^{-1}$ and $125 \mathrm{mg} \mathrm{N}_{-} \mathrm{NO}_{3}{ }^{-} \mathrm{l}^{-1}$ and complete denitrification took place in all cases. Formaldehyde was completely biodegraded in less than $30 \mathrm{~h}$, while the denitrification process lasted several days. Therefore, formaldehyde was transformed into other organic compounds which were then used as carbon sources for denitrification. Possible products of formaldehyde biodegradation are methanol and formic acid. Similar assays performed in our laboratory with the same sludge and studies with the continuous reactor described further in this paper confirmed that formaldehyde was transformed into both methanol and formic acid. This is in agreement with results obtained by other authors studying formaldehyde biodegradation by a strain of Pseudomonas putida ( Kato et al., 1983). The authors found an enzyme which catalyzed dismutation of formaldehyde to form methanol and formic acid. Adroer et al. (1990) showed that degradation of methanol and formic acid began after exhaustion of formaldehyde in the medium. 

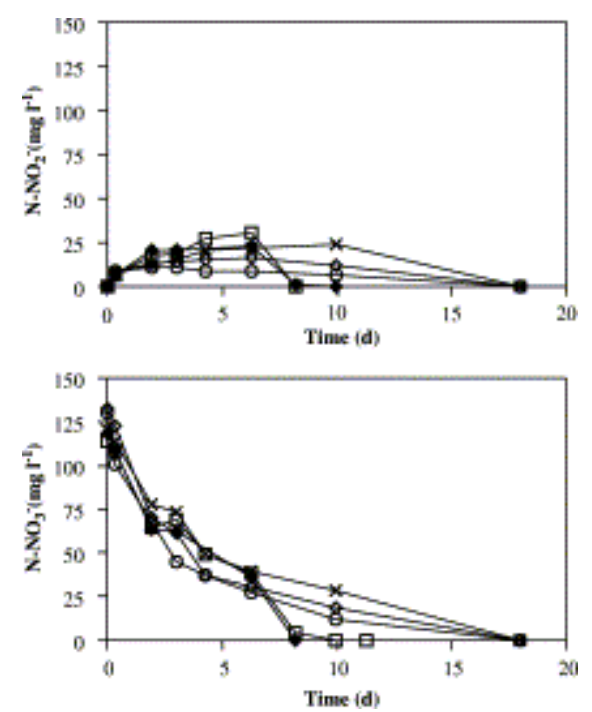

Fig. 2.

Denitrification process in presence of $430 \mathrm{mg} \mathrm{l}^{-1}$ formaldehyde and $(\circ) 0,(\diamond)$ 90, (×) 180, (口) 280, (•) $370 \mathrm{mg} \mathrm{N}-\mathrm{NH}_{2} \mathrm{CONH}_{2} \mathrm{l}^{-1}$.

Fig. 2 shows that the overall denitrification process was not affected by the initial urea concentration (from 90 to $370 \mathrm{mg} \mathrm{N}-\mathrm{NH}_{2} \mathrm{CONH}_{2} \mathrm{l}^{-1}$ ). At higher initial urea concentrations, nitrate was even eliminated much faster. However, an increase in the initial urea concentration led to a slightly higher accumulation of nitrite (always less than $30 \mathrm{mg} \mathrm{l}^{-1}$ ), which was later eliminated. The denitrification was not inhibited in spite of the high ammonia concentrations reached in the assays. $\mathrm{pH}$ was between 7.3 and 8.7 and the final free ammonia concentrations were 2.8, 7.8, 42.2 and $77.9 \mathrm{mg} \mathrm{N}-$ $\mathrm{NH}_{3} \mathrm{l}^{-1}$ for, respectively, 90, 180, 280 and $370 \mathrm{mg} \mathrm{N}-\mathrm{NH}_{2} \mathrm{CONH}_{2} \mathrm{l}^{-1}$.

\subsection{Continuous reactor}

\subsubsection{Formaldehyde biodegradation}

In order to study formaldehyde biodegradation in the continuous lab-scale reactor, the amount of formaldehyde in the influent was increased from 625 up to $5000 \mathrm{mg} \mathrm{l}^{-1}$. The evolution of its concentration is shown in Fig. 3A. High formaldehyde removal efficiencies, above 99.5\%, were obtained at all the applied organic loading rates, between 0.37 and $2.96 \mathrm{~kg} \mathrm{COD} \mathrm{m}^{-3} \mathrm{~d}^{-1}$. The unit remained stable throughout the more than 7 months operation with very low formaldehyde concentrations in the effluent, below $10.3 \mathrm{mg} \mathrm{l}^{-1}$. Formaldehyde removal was not affected by the urea loading rate in the system. These data indicate that the continuous anoxic treatment of wastewaters with high levels of formaldehyde in the presence of urea, as in the case of wastewaters from synthetic resin producing factories, can efficiently be undertaken. Garrido et al. (2001) working with a multifed upflow filter, increased the formaldehyde loading rate up to $4.3 \mathrm{~kg} \mathrm{COD} \mathrm{m}^{-3} \mathrm{~d}^{-1}$ and found that the removal rate did not exceed $2.1 \mathrm{~kg}$ COD m ${ }^{-3} \mathrm{~d}^{-1}$ under anoxic conditions in the presence of urea. In our case, a higher formaldehyde removal rate (2.96 $\mathrm{kg} \mathrm{COD} \mathrm{m}^{-3} \mathrm{~d}^{-1}$ ) was obtained without inhibition. 

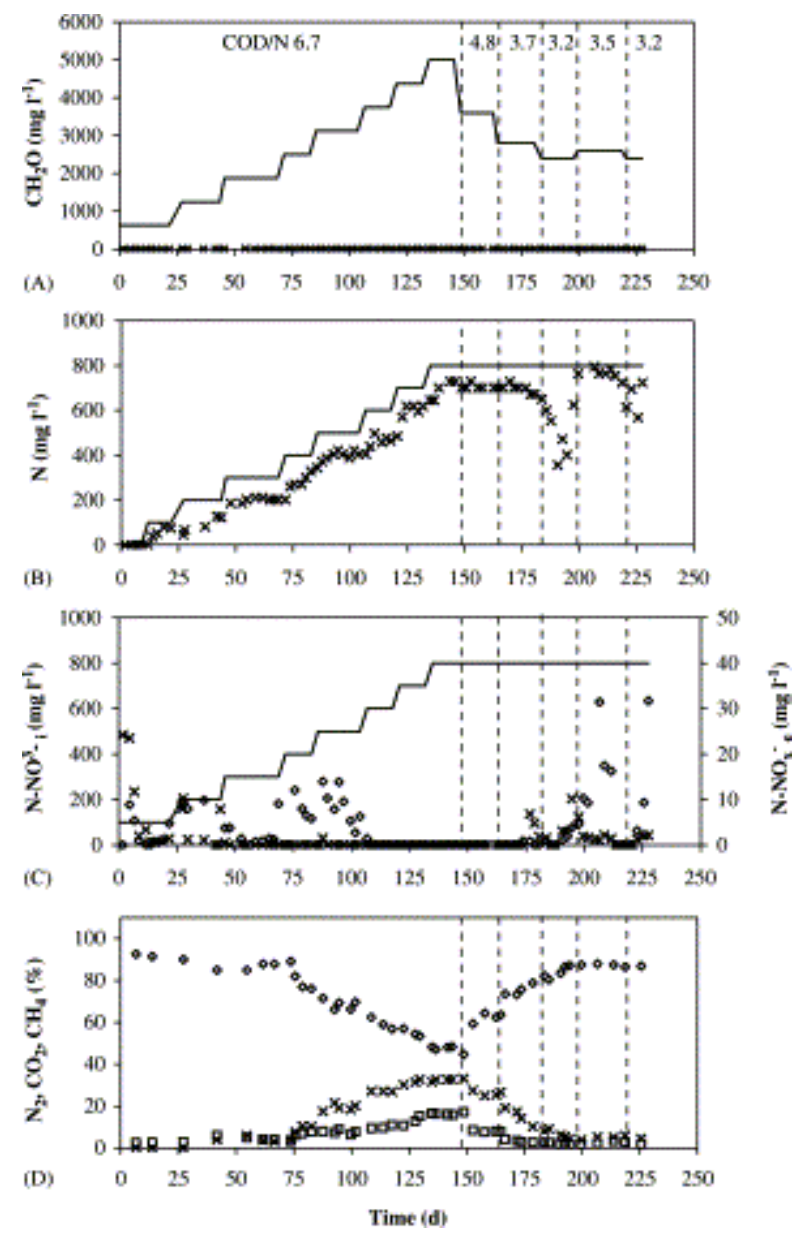

Fig. 3.

(A) Formaldehyde concentration in the influent $(-)$ and effluent $(\times)$ of the continuous reactor. (B) Urea concentration in the influent $(-)$ and ammonium concentration in the effluent $(\times)$ of the continuous reactor. (C) Nitrate in the influent $(-)$ and nitrate $(-)$ and nitrite $(\diamond)$ in the effluent of the continuous reactor. (D) Evolution of biogas composition: nitrogen $(\diamond)$, carbon dioxide $(\square)$ and methane $(\times)$.

In spite of the almost complete formaldehyde removal, a COD fraction of the influent was present in the effluent of the unit, indicating the possible existence of biodegradation products. Some of the remaining COD in the effluent could also be due to extra enzymes or inert bio-products released from the sludge in the reactor caused by turbulent shear stress. The percentage of remaining COD in the effluent was of $12.7 \%$ at the highest formaldehyde concentration applied, being the mean value of $7.2 \%$. As it has been indicated before, formaldehyde removal can lead to the appearance in the medium of methanol and formic acid; for that reason these compounds were measured. Methanol and formic acid were sporadically detected at low concentrations in the effluent (up to $100 \mathrm{mg} \mathrm{CH}_{3} \mathrm{OH} \mathrm{l}^{-1}$ and $150 \mathrm{mg} \mathrm{HCOOH} \mathrm{l}^{-1}$ ) as products of formaldehyde biodegradation, especially immediately after changes in the formaldehyde concentration in the influent. Therefore, in the treatment of wastewaters with formaldehyde it is necessary to control the operation conditions in order to avoid the presence of methanol and formic acid in the effluent. 


\subsubsection{Urea hydrolysis}

The urea hydrolysis generates ammonium, as well as an increase of the carbon dioxide fraction in the gas phase. The evolution of the ammonium concentration was analyzed in order to evaluate the level of urea hydrolysis (Fig. 3B). The urea loading rate was increased from 0.06 to $0.44 \mathrm{~kg} \quad \mathrm{~N}-\mathrm{NH}_{2} \mathrm{CONH}_{2} \mathrm{~m}^{-3} \mathrm{~d}^{-1} \quad(100-800 \mathrm{mg} \mathrm{N}-$ $\mathrm{NH}_{2} \mathrm{CONH}_{2} \mathrm{l}^{-1}$ ) and urea was almost completely hydrolyzed. From the mass balances calculated on the basis of the amount of urea fed to the reactor and the ammonium levels in the effluent, a mean value of $77.5 \%$ of urea conversion to ammonium could be accounted for. The unaccounted portion can be attributed to microbial assimilation as well as to abiotic ammonium loss.

The results are comparable with the ones obtained by Garrido et al. (2001) working under anoxic conditions. At a urea loading rate of $0.46 \mathrm{~kg} \mathrm{~N}-\mathrm{NH}_{2} \mathrm{CONH}_{2} \mathrm{~m}^{-3} \mathrm{~d}^{-1}$, they obtained a hydrolysis between 65 and $85 \%$. The hydrolysis percentages reached in our study were higher than those obtained by these authors, at a urea loading rate of $0.44 \mathrm{~kg}$ $\mathrm{N}-\mathrm{NH}_{2} \mathrm{CONH}_{2} \mathrm{~m}^{-3} \mathrm{~d}^{-1}$, 90.5\% urea hydrolysis was reached without inhibition. However, these values are lower than those obtained by Latkar and Chakrabarti (1994) using an anaerobic system and reaching a urea hydrolysis rate of $1.5 \mathrm{~kg} \mathrm{~N} / \mathrm{m}^{-3} \mathrm{~d}^{-1}$ with an efficiency of $100 \%$.

\subsubsection{Denitrification process in the presence of formaldehyde and urea}

Biological denitrification in the presence of formaldehyde and urea was also studied in the continuous lab-scale reactor. The evolution of nitrate and nitrite concentrations is shown in Fig. 3C. The COD/N ratio was maintained at 6.7 until day 148 of operation, ranging the influent nitrate concentrations from 100 to $800 \mathrm{mg} \mathrm{N}-\mathrm{NO}_{3}{ }^{-} \mathrm{l}^{-1}$. High denitrification percentages were obtained at all the applied nitrate loading rates, up to $0.44 \mathrm{~kg} \mathrm{~N}-\mathrm{NO}_{3}^{-} \mathrm{m}^{-3} \mathrm{~d}^{-1}$. The mean denitrification efficiency was $98.4 \%$, although occasionally nitrite appeared in the effluent, at a concentration always less than $25 \mathrm{mg} \mathrm{l}^{-1}$. No loss of denitrification efficiency was observed when the formaldehyde concentration was increased to a value as high as $5000 \mathrm{mg} \mathrm{l}^{-1}$. Therefore, it can be concluded that formaldehyde was used efficiently as an electron donor for denitrification. Moreover, the denitrification process was apparently not affected by the urea loading rate in the system. At higher urea concentrations in the influent, the denitrification percentage was even higher. $\mathrm{pH}$ was between 7.6 and 8.7 (mean value 8.2) and the ammonium concentration in the effluent reached $730 \mathrm{mg} \mathrm{N}-\mathrm{NH}_{4}^{+} \mathrm{l}^{-1}$. Consequently, the free ammonia concentration varied between 3 and $110 \mathrm{mg} \mathrm{N}-$ $\mathrm{NH}_{3} \mathrm{l}^{-1}$, throughout the operation period. The denitrification process was not inhibited by this high free ammonia concentration.

The percentages of nitrogen, carbon dioxide and methane in the biogas varied between 91.5-47.2\%, 2.7-16.5\% and 0-32.8\%, respectively (Fig. 3D). Nitrous oxide was never detected in the gas phase. From these results it is clear that two processes, denitrification and methanogenesis, occurred together in the same unit at a COD/N ratio of 6.7 until day 148 of operation. Previous studies indicate that if there is enough carbon source in the influent, both processes can occur in the same system (Akunna et al., 1992). In such case, methanogenesis starts once denitrification has been completed and the surplus carbon source is then effectively converted to methane and subsequently a low effluent COD concentration is reached (Chen and Lin, 1993; Her and Huang, 
1995). The advantage of the use of denitrification and methanogenesis together is that the remaining COD after denitrification can be removed by methanogenic bacteria.

After day 148 of operation, the $\mathrm{COD} / \mathrm{N}$ ratio in the influent was changed. The nitrate concentration was maintained at $800 \mathrm{mg} \mathrm{N}^{-1}$ while decreasing the formaldehyde concentration. The formaldehyde biodegradation, urea hydrolysis and denitrification processes remained unchanged at $\mathrm{COD} / \mathrm{N}$ ratios of 4.8 and 3.7 (Fig. 3). With the decrease of the $\mathrm{COD} / \mathrm{N}$ ratio, the percentage of nitrogen in the biogas increased, whereas the percentage of methane decreased (Fig. 3D). Denitrifying bacteria outcompeted methanogenic bacteria for the carbon source, finally resulting in a loss of methanogenic activity. When the $\mathrm{COD} / \mathrm{N}$ ratio was decreased to 3.2 (day 184 of operation), nitrate and nitrite concentrations in the effluent rose due to a shortage of carbon source (Fig. 3C). Afterwards, the $\mathrm{COD} / \mathrm{N}$ ratio was increased to 3.5, which led to the recovery of the denitrification efficiency. Once the COD/N ratio in the influent returned to 3.2 (day 221 of operation), the unit lost again efficiency. The theoretical formaldehyde requirement for denitrifying nitrate, neglecting carbon assimilation, corresponds to a $\mathrm{COD} / \mathrm{N}$ ratio of 2.9. In practice, this ratio is higher due to biomass synthesis. In our study, the minimum $\mathrm{COD} / \mathrm{N}$ ratio that allowed reaching almost complete denitrification was 3.5.

\subsubsection{Granulation of sludge}

The biomass concentration in the reactor increased from an initial value of 8-17.5 $\mathrm{g}$ VSS l$^{-1}$ after more than 7 months operation. No biomass was purged from the reactor during the whole experimental period. The biomass concentration in the effluent varied between 0.002 and $0.282 \mathrm{~g} \mathrm{VSS} \mathrm{l}^{-1}$ during all the operation time, with a mean value of $0.080 \mathrm{~g} \mathrm{VSS} \mathrm{l}^{-1}$. Sludge with good settling properties and a satisfactory effluent with low concentrations of suspended solids were obtained.

Granulation of the sludge was observed in the sludge blanket reactor at an upflow velocity of $0.14 \mathrm{~m} \mathrm{~h}^{-1}$. Part of the sludge began to form pellets $65 \mathrm{~d}$ after the start-up, but clear granulation was not visible until day 90 of operation. From this time to the end of the reactor operation, sludge granules between 0.5 and $2 \mathrm{~mm}$ were clearly visible. Therefore, it was possible to develop a granular sludge using activated sludge as inoculum. The granules were fairly fragile, they were stable in the sludge bed but after removal from the reactor they were easily pulverized. Before granulation, episodes of floating sludge occurred. During this period, retention of gas bubbles was observed in the sludge bed, causing the bed to rise. The development of granules resulted in better settling characteristics of the sludge.

Granulation has recently been reported in the literature in upflow sludge blanket denitrifying reactors (Kratochvil et al., 1996; Borzacconi et al., 1999; Rouse et al., 1999). Granulation is clearly influenced by precipitation of calcium salts at high $\mathrm{pH}$ levels reached as a result of denitrification, which might create a matrix for granulation of the sludge. Methanogenic bacteria could also play an important role in the granulation process since many methanogens usually grow in large aggregates. In our study, granular sludge was obtained using a feed solution with an alkalinity ranging between 150 and $250 \mathrm{mg} \mathrm{l}^{-1} \mathrm{CaCO}_{3}$. This is in agreement with data found in the literature. Kratochvil et al. (1996) working with an anoxic upflow sludge blanket reactor, found that it was possible to obtain granular sludge with $50 \mathrm{mg} \mathrm{l}^{-1} \mathrm{CaCO}_{3}$. 
Samples of the sludge were observed by scanning electron microscopy (Fig. 4). The granules were irregularly shaped and had an apparently porous surface which could favor the diffusion of the substrates into the granules and the outdiffusion of the biogas. Higher magnification showed that the surface and the internal structure consisted of closely packed, rod-shaped bacteria, together with some cocci embedded in an extended matrix (Fig. 4). This matrix could be made of extracellular polymers typically produced by methanogenic organisms (Veiga et al., 1997). This is similar to the anoxic granules described by Kratochvil et al. (1996).

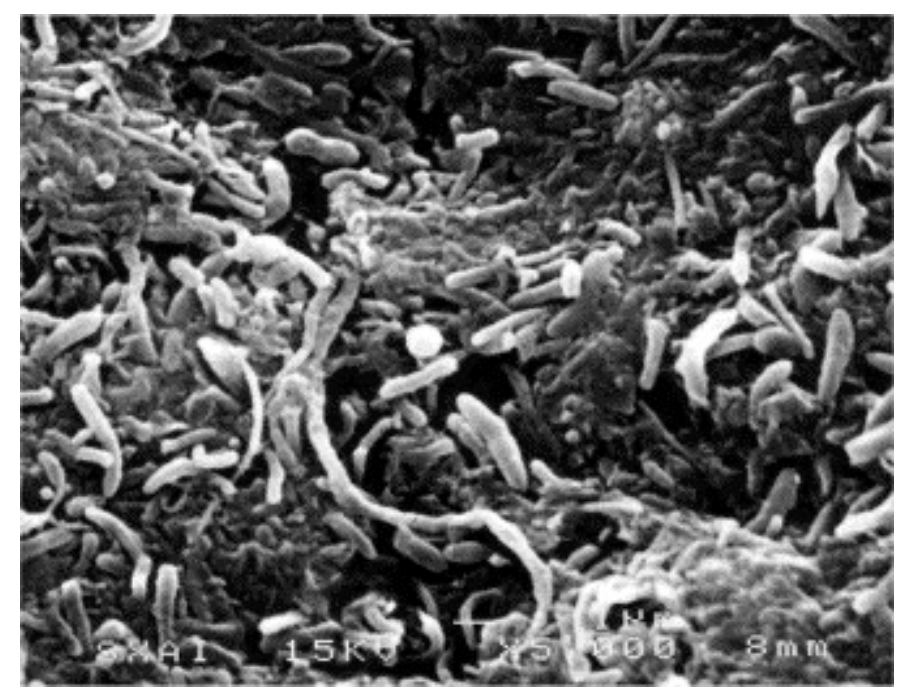

Fig. 4.

Sludge observed by scanning electron microscopy.

\subsection{Conclusions}

\subsubsection{Batch assays}

Complete formaldehyde biodegradation and denitrification took place in all assays (430 mg $\mathrm{CH}_{2} \mathrm{O} \mathrm{l}^{-1}$ and $125 \mathrm{mg} \mathrm{N}-\mathrm{NO}_{3}{ }^{-} \mathrm{l}^{-1}$ ). The initial formaldehyde biodegradation rates remained almost constant (around $0.7 \mathrm{~g} \mathrm{CH}_{2} \mathrm{O} \mathrm{g} \mathrm{VSS}^{-1} \mathrm{~d}^{-1}$ ) at urea concentrations ranging from 90 to $370 \mathrm{mg} \mathrm{N}-\mathrm{NH}_{2} \mathrm{CONH}_{2} \mathrm{l}^{-1}$. Urea was completely hydrolyzed to ammonium in the presence of formaldehyde. The data show that formaldehyde removal and the overall denitrification process were not affected by the initial urea concentration.

\subsubsection{Continuous reactor}

High formaldehyde removal efficiencies, above 99.5\%, were obtained at all the applied organic loading rates, between 0.37 and $2.96 \mathrm{~kg} \mathrm{COD} \mathrm{m}^{-3} \mathrm{~d}^{-1}\left(625-5000 \mathrm{mg} \mathrm{CH}_{2} \mathrm{O} \mathrm{l}^{-1}\right)$. The urea loading rate was increased from 0.06 to $0.44 \mathrm{~kg} \mathrm{~N}-\mathrm{NH}_{2} \mathrm{CONH}_{2} \mathrm{~m}^{-3} \mathrm{~d}^{-1}(100-$ $800 \mathrm{mg} \mathrm{N}-\mathrm{NH}_{2} \mathrm{CONH}_{2} \mathrm{l}^{-1}$ ). Urea was almost completely hydrolysed, being $77.5 \%$ the mean value of urea conversion to ammonium.

High denitrification percentages were obtained at all the applied nitrate loading rates, up to $0.44 \mathrm{~kg} \mathrm{~N}-\mathrm{NO}_{3}{ }^{-} \mathrm{m}^{-3} \mathrm{~d}^{-1}\left(100-800 \mathrm{mg} \mathrm{N}-\mathrm{NO}_{3}{ }^{-} \mathrm{l}^{-1}\right)$. While the $\mathrm{COD} / \mathrm{N}$ ratio was maintained at 6.7, the mean denitrification efficiency was of $98.4 \%$. Afterwards, the 
$\mathrm{COD} / \mathrm{N}$ ratio in the influent was decreased requiring a minimum $\mathrm{COD} / \mathrm{N}$ ratio of 3.5 to reach almost complete denitrification. Granulation of the sludge was observed in the upflow sludge blanket reactor.

These data indicate that the continuous anoxic treatment of wastewater with high levels of formaldehyde in the presence of urea and nitrate, as in the case of wastewaters from synthetic resin producing factories, can efficiently be undertaken.

\section{Acknowledgements}

The present research has been funded by the Spanish Ministry of Science and Technology, Projects REN2000-0218-P4-02, PPQ2002-02882 and the Xunta de Galicia, Project PR 425C 2003/114-0. M. Eiroa is grateful to the Spanish Ministry of Education and Culture for a fellowship.

\section{References}

N. Adroer, C. Casas, C. de Mas, C. Solá

Mechanism of formaldehyde biodegradation by Pseudomonas putida

Appl. Microbiol. Biotechnol., 33 (1990), pp. 217-220

J.C. Akunna, C. Bizeau, R. Moletta

Denitrification in anaerobic digesters: possibilities and influence of wastewater $\mathrm{COD} / \mathrm{N}-\mathrm{NO}_{X}{ }^{-}$ratio

Environ. Technol., 13 (1992), pp. 825-836

APHA, 1998. Standard Methods for the Examination of Water and Wastewater, 20th ed. Washington DC, USA.

M. Azachi, Y. Henis, A. Oren, P. Gurevich, S. Sarig

Transformation of formaldehyde by a Halomonas sp

Can. J. Microbiol., 41 (1995), pp. 548-553

L. Borzacconi, G. Ottonello, E. Castelló, H. Pelaez, A. Gazzola, M. Viñas

Denitrification in a carbon and nitrogen removal system for leachate treatment: performance of an upflow sludge blanket (USB) reactor

Water Sci. Technol., 40 (8) (1999), pp. 145-151

Cantó, M., Gómez, J., Kennes, C., Veiga, M.C., 1998. Integrated anoxic-aerobic treatment of wastewaters from a synthetic resin producing factory. European Conference on New Advances in Biological Nitrogen and Phosphorus Removal for Municipal or Industrial Wastewaters, Narbonne, France, pp. 289-292.

K.C. Chen, Y.F. Lin

The relationship between denitrifying bacteria and methanogenic bacteria in a mixed culture system of acclimated sludges

Water Res., 27 (12) (1993), pp. 1749-1759 
M. Eiroa, C. Kennes, M.C. Veiga

Formaldehyde biodegradation and its inhibitory effect on nitrification

J. Chem. Technol. Biotecnol., 79 (2004)

J.M. Garrido, R. Méndez, J.M. Lema

Simultaneous urea hydrolysis, formaldehyde removal and denitrification in a multifed upflow filter under anoxic and anaerobic conditions

Water Res., 35 (3) (2001), pp. 691-698

J. Her, J. Huang

Influences of carbon source and $\mathrm{C} / \mathrm{N}$ ratio on nitrate/nitrite denitrification and carbon breakthrough

Bioresource Technol., 54 (1995), pp. 45-51

A. Hidalgo, A. Lopategi, M. Prieto, J.L. Serra, M.J. Llama

Formaldehyde removal in synthetic and industrial wastewater by Rhodococcus erythropolis UPV-1

Appl. Microbiol. Biotechnol., 58 (2002), pp. 260-263

N. Kato, K. Shirakawa, H. Kobayashi, C. Sakazawa

The dismutation of aldehydes by a bacterial enzyme

Agric. Biol. Chem., 47 (1) (1983), pp. 39-46

K. Kratochvil, D.A.J. Wase, C.F. Forster

The formation and characterization of a granular sludge in an anoxic usb reactor

Trans. IChemE., 74 (B) (1996), pp. 94-98

M. Latkar, T. Chakrabarti

Performance of upflow anaerobic sludge blanket reactor carrying out biological hydrolysis of urea

Water. Environ. Res., 66 (1) (1994), pp. 12-15

Z. Lu, W. Hegemann

Anaerobic toxicity and biodegradation of formaldehyde in batch cultures

Water. Res., 32 (1) (1998), pp. 209-215

T. Nash

The colorimetric estimation of formaldehyde by means of the hantzch reaction

Biochem. J., 55 (1953), pp. 416-421

F. Omil, D. Méndez, G. Vidal, R. Méndez, J.M. Lema

Biodegradation of formaldehyde under anaerobic conditions

Enzyme Microbiol. Technol., 24 (1999), pp. 255-262

Ó.J. Prado, M. Eiroa, M.C. Veiga, C. Kennes

Bioreactors for the treatment of industrial waste gases containing formaldehyde and other aliphatic compounds

S.N. Agathos, W. Reineke (Eds.), Focus on Biotechnology, Vol. 3CKluwer Academic Publishers, Dordrecht, The Netherlands (2003), pp. 259-273 
M. Qu, S.K. Bhattacharya

Toxicity and biodegradation of formaldehyde in anaerobic methanogenic culture

Biotechnol. Bioeng., 55 (5) (1997), pp. 727-736

J.D. Rouse, K. Sumida, K. Kida, K. Furukawa

Maintainability of denitrifying granular sludge in soft to marginally hard waters in an upflow sludge-blanket reactor

Environ. Technol., 20 (1999), pp. 219-225

M.C. Veiga, M. Soto, R. Méndez, J.M. Lema

A new device for measurement and control of gas production by bench scale anaerobic digesters

Water Res., 24 (12) (1990), pp. 1551-1554

M.C. Veiga, M.K. Jain, W.M. Wu, R.I. Hollingsworth, J.G. Zeikus

Composition and role of extracellular polymers in methanogenic granules

Appl. Environ. Microbiol., 63 (2) (1997), pp. 403-407

T. Yamazaki, W. Tsugawa, K. Sode

Biodegradation of formaldehyde by a formaldehyde-resistant bacterium isolated from seawater

Appl. Biochem. Biotechnol., 91-93 (2001), pp. 213-217 